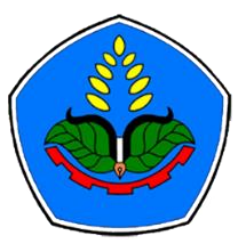

AGROPROSS

National Conference

Proceedings of Agriculture

\section{Proceedings: \\ Peran Teaching Factory di Perguruan Tinggi Vokasi Dalam Mendukung Ketahanan Pangan Pada Era New Normal}

Tempat : Politeknik Negeri Jember

Tanggal : 8-9 Juli 2020

\section{Publisher:}

Agropross, National Conference Proceedings of Agriculture ISBN : 978-623-94036-6-9

DOI : 10.25047 /agropross.2020.26

\title{
Efektivitas Keberhasilan Okulasi Cokelat dengan Jenis Klon dan Pemberian Pupuk pada Pembibitan Tanaman Karet
}

\author{
Author(s): Hidayati Fatchur Rochmah ${ }^{(1)^{*}}$ dan Fauzan Syahputra Ramdani( ${ }^{(1)}$ \\ (1) Program Studi Teknologi dan Manajemen Perkebunan, Sekolah Vokasi IPB \\ * Corresponding author: hidayatifatchur@apps.ipb.ac.id
}

\begin{abstract}
Plants are the country's No. 2 foreign exchange earner. One of the causes of low rubber productivity is smallholder farmers who lack the proper cultivation technology and rarely use recommended superior clones according to standards. The purpose of this study was to determine the effect of the use of clones and the addition of fertilizers on the success of chocolate grafting and rubber seedling growth. The study was conducted on January 14 - April 1, 2020 at Pasir Ucing Estate, PT Pasir Ucing, Bandung, West Java. This study uses two factors, namely the treatment of brown grafting stem clones, namely: (K1) PR 261 clone and (K2) PR 300 clone and Fertilizer treatment, namely: (P1) No fertilizer and (P2) Fertilizer. Each treatment was repeated three times and each experimental unit contained three seeds, so that the total treatment was 36 experimental units. Observations observed are; planting material, percentage of grafting success, percentage of leaf, shoot height, shoot diameter and seedling maintenance. The results showed that the treatment of the top stem clone PR 261 was better than the top stem clone PR 300. The addition of fertilizer resulted in a high growth of rubber seedling shoots of $6.97 \mathrm{~cm}$ and a diameter of $0.29 \mathrm{~cm}$. The combination of PR 261 clone treatment and urea fertilizer $4 \mathrm{~g}$ polybag-1, Sp-36 $2 \mathrm{~g}$ polybag-1 and KCL $1 \mathrm{~g}$ polybag-1 increased the growth of rubber seedlings.
\end{abstract}

Keyword:

Brown grafting;

Clone;

Fertilizer;

Seedling;

\section{Kata Kunci:}

Klon;

Okulasi cokelat;

Pembibitan;

Pupuk;

\begin{abstract}
ABSTRAK
Tanaman merupakan tanaman penghasil devisa negara no 2. Salah satu penyebab produktivitas karet rendah adalah petani perkebunan rakyat yang kurang menguasai teknologi budidaya yang tepat dan jarang menggunakan klon-klon unggul anjuran sesuai standar. Tujuan dari penelitian ini yaitu untuk mengetahui pengaruh penggunaan jenis klon dan penambahan pupuk terhadap keberhasilan okulasi cokelat dan pertumbuhan bibit karet. Penelitian dilaksanakan pada tanggal 14 Januari - 1 April 2020 di Kebun Pasir Ucing, PT Pasir Ucing, Bandung, Jawa Barat. Penelitian ini menggunakan dua faktor yaitu perlakuan klon batang atas okulasi coklat yaitu : (K1) Klon PR 261 dan (K2) Klon PR 300 serta perlakuan Pupuk yaitu : (P1) Tanpa Pupuk dan (P2) Pupuk. Setiap perlakuan diulang tiga kali dan setiap satuan percobaan terdapat tiga bibit, sehingga total perlakuan yaitu 36 satuan percobaan. Pengamatan yang diamati yaitu; bahan Tanam, prosentase keberhasilan okulasi, prosentase daun, tinggi tunas, diameter tunas dan pemeliharaan Bibit. Hasil penelitian menunjukkan bahwa perlakuan klon batang atas PR 261 lebih baik dibanding klon batang atas PR 300. Penambahan pupuk menghasilkan pertumbuhan tinggi tunas bibit karet sebesar $6,97 \mathrm{~cm}$ dan diameter sebesar $0.29 \mathrm{~cm}$. Kombinasi Perlakuan klon PR 261 dan pupuk urea 4 g polybag ${ }^{-1}, \mathrm{Sp}-36$ $2 \mathrm{~g}_{\text {polybag }}{ }^{-1}$ dan KCL $1 \mathrm{~g} \mathrm{polybag}^{-1}$ meningkatkan pertumbuhan bibit karet.
\end{abstract}




\section{PENDAHULUAN}

Komoditas karet merupakan penyumbang devisa negara ke dua setelah komoditas kelapa sawit dan menjadi komoditas sektor ekonomi penting bagi penduduk Indonesia. Nilai ekspor karet mencapai US\$ 5.1 juta dengan volume ekspor tahun 2017 mencapai 2991909 ton mengalami peningkatan sebesar $9.69 \%$ dibandingkan pada tahun 2013 sebesar 2 701995 ton dalam bentuk karet alam dan turunan pengolahannya (Ditjenbun, 2018).

Pada tahun 2017 produksi tanaman karet nasional mencapai 3680428 ton mengalami peningkatan sebesar $12.04 \%$ dibandingkan dengan tahun 2013 yang mencapai 3237433 ton. Peningkatan produksi karet tersebut diakibatkan adanya peningkatan produktivitas pada tahun 2017 mencapai $1410 \quad \mathrm{~kg} \mathrm{ha}^{-1}$ mengalami peningkatan $5.8 \%$ dibandingkan dengan produktivitas tahun 2013 yang mencapai 1 $328 \mathrm{~kg} \mathrm{ha}^{-1}$ dan dipengaruhi penambahan luas areal pada tahun 2017 mencapai 3659 090 ha dengan persentase peningkatan sebesar $2.49 \%$ dibandingkan pada tahun 2013 yang mencapai 3555946 ha. Persentase luas areal yang ditanam terbesar $84.81 \%$ pada perkebunan rakyat, $8.82 \%$ pada perkebunan swasta dan terendah $6.37 \%$ pada perkebunan negara (Ditjenbun, 2018).

Banyak faktor yang menjadi penyebab produktivitas karet rendah dibanding negara penghasil karet lainnya. Penyebabnya adalah petani perkebunan rakyat yang kurang menguasai teknologi budidaya salah satunya banyak petani tidak menggunakan klon-klon unggul anjuran sesuai standar. Perbanyakkan bibit unggul karet masih sangat dibutuhkan. Pemenuhan kebutuhan bibit unggul tersebut diperlukan teknik okulasi yang tepat. Okulasi digunakan untuk mempertahankan sifat induk yang dimiliki salah satunya produksi lateks. Perbanyakan bibit secara okulasi di Indonesia banyak digunakan karena tanaman karet yang berasal dari biji, meskipun dari jenis unggul, tidak menjamin keturunannya akan memiliki sifat baik seperti pohon induknya akibat terjadinya segregasi dari hasil persarian sendiri (selfing) dan atau silang luar (outcrossing) dari genotipe heterozigot. Penggunaan okulasi cokelat mampu menghasilkan bibit siap salur12-18 sejak perkecambahan (Boerhendy, 2013).

Peran bibit dan klon unggul dalam peningkatan produktivitas tanaman karet cukup tinggi, yaitu sekitar $60 \%$, selebihnya atau sekitar $40 \%$ dipengaruhi oleh faktor lingkungan dan pengelolaan kebun. Semakin baik mutu bibit dan klon yang digunakan, minimal $60 \%$ potensi produksi dapat dicapai. Sebaliknya, bila mutu bibit rendah, maka produktivitasnya akan tetap rendah, meskipun dilakukan pemeliharaan secara maksimal. Produktivitas tanaman asal biji (seedling) maksimal hanya $40 \%$ dari tanaman klonal. Sementara itu, produktivitas tanaman klonal dengan entres yang berasal dari cabang tanaman, produktivitasnya maksimal $60 \%$ dari tanaman klonal dengan sumber entres yang berasal dari kebun entres (Hadi, 2010).

Penggunaan jenis klon berpengaruh terhadap hasil lateks yang dihasilkan oleh tanaman karet. Jenis klon karet yang direkomendasikan di PT Pasir Ucing adalah PR 261 dan PR 300. Klon PR 261 dan PR 300 merupakan jenis klon penghasil lateks. Klon PR 261, BPM 24, RRIM 703, PR 255, PR 300 dan GT 1 merupakan jenis klon yang direkomendasikan untuk ditanam pada lahan marginal dengan tekstur tanah lempung berpasir sampai pasir berlempung serta periode bulan kering yang tegas (Tjahyana \& Ferry, 2011).

Keberhasilan dan pertumbuhan bibit karet selain dipengaruhi oleh jenis klon juga dipengaruhi oleh pemeliharaan bibit. Penambahan pupuk pada saat sebelum okulasi dilakukan diharapkan dapat meningkatkan keberhasilan okulasi cokelat dan pertumbuhan bibit karet yang baik. 
Pemupukan bertujuan untuk menambahkan unsur hara yang dibutuhkan oleh tanaman. Pemberian pupuk fosfor pada bibit karet nyata menghasilkan panjang tunas, bobot basah dan kering akar dengan pola respon linier (Hulu \& Supijatno, 2016). Hasil penelitian menunjukkan perlakuan pupuk NPK berpengaruh nyata terhadap tinggi dan diameter batang umur 3 dan 4 bulan setelah okulasi serta jumlah daun saat 4 bulan telah okulasi (Selwina \& Sutejo, 2017)

Tujuan dari penelitian ini yaitu untuk mengetahui pengaruh penggunaan jenis klon dan penambahan pupuk terhadap keberhasilan okulasi cokelat serta pertumbuhan bibit karet yang lebih baik.

\section{BAHAN DAN METODE}

Penelitian ini dilaksanakan di Kebun Pasir Ucing, PT Pasir Ucing, Bandung Barat, Jawa Barat. PT Pasir Ucing terletak pada $06^{\circ} 44^{\prime} 35.05^{\prime \prime}$ - $06^{\circ} 47^{\prime} 22.31$ ' Lintang Selatan dan $107^{\circ} 21^{\prime} 28.98^{\prime \prime}$ Bujur timur. Lokasi perusahaan berada pada Kampung Pasir Ucing, Desa Nanggeleng, Kecamatan Cipeundeuy, Kabupaten Bandung barat, Provinsi Jawa barat. Pelaksanaan penelitian yaitu 14 Januari-1April 2020. Bahan yang diperlukan dalam penelitian ini yaitu bibit batang bawah, mata entres PR261, PR300, polybag ukuran $25 \mathrm{~cm}$ x 40 $\mathrm{cm}$ dan plastik. Alat yang diperlukan yaitu thermohygrometer, lux meter, pisau okulasi, pH meter, meteran, jangka sorong, cangkul, paranet dan emrat.

Rancangan percobaan yang digunakan yaitu Rancangan Acak Kelompok (RAK) dengan 2 faktorial yaitu faktor klon dan pupuk. Perlakuan klon yaitu klon PR260 (K0) dan PR 300 (K1), perlakuan pupuk yaitu tanpa pupuk (P0) dan + pupuk (P1). Setiap perlakuan diulang 3 kali, dengan setiap perlakuan terdiri atas 3 bibit sehingga didapatkan 36 satuan percobaan. Analisis ragam yang digunakan yaitu $Y i j=\mu+\alpha i+\beta j+\gamma k+\varepsilon i j k$, dimana $\mathrm{i}$ $: 1,2 ; \mathrm{j}: 1,2 ; \mathrm{k}=1,2,3$; Yijk : pengamatan pada perlakuan klon ke-i, perlakuan pupuk ke-j, ulangan ke-k; $\mu$ : rataan populasi; $\alpha \mathrm{i}$ : pengaruh perlakuan klon ke-i; $\beta \mathrm{j}$ : pengaruh perlakuan pupuk ke-j; $\gamma \mathrm{k}$ : pengaruh ulangan ke-k; eijk: pengaruh perlakuan klon ke-I, pupuk ke-j dan ulangan ke-k. Jika hasil sidik ragam menunjukkan pengaruh yang nyata pada uji $\mathrm{F}$ taraf 5\%, maka dilakukan perbandingan antara rataan perlakuan dengan uji DMRT (Duncan Multiple Range Test) pada taraf $\alpha$ 5\% (Gomez \& Gomez, 2007).

Pengamatan yang diamati selama penelitian yaitu iklim mikro, diameter batang bawah, prosentase perubahan warna cambium diamati 1 dan 2 minggu setelah okulasi, prosentase keberhasilan okulasi diamati 1 dan 2 minggu setelah okulasi, prosentase pertumbuhan daun diamati 1-4 minggu setelah okulasi, prosentase munculnya tunas diamati $7,12,15$ hari setelah okulasi, tinggi tunas dan diameter tunas diamati setiap bulan setelah okulasi.

Okulasi yang digunakan adalah okulasi batang cokelat. Batang bawah dipilih dari benih asalan yang berasal dari perkebunan. Batang bawah dibibitkan terlebih dahulu sampai umur 1 bulan. Media tanam yang digunakan yaitu tanah dengan pupuk kandang dengan perbandingan 1:1. Tanaman yang diambil sebagai mata entres telah berumur 15 tahun yang berasal dari tanaman induk dan sudah diketahui produksinya. Okulasi dilakukan dengan cara membuat jendela dengan ketinggian $\pm 10 \mathrm{~cm}$ dari pangkal batang, lebar jendela $1.5-2 \mathrm{~cm}$ dan panjang jendela 5-10 cm. Mata entres diambil dan disisipkan pada jendela batang bawah. Hasil okulasi ditutup dengan plastik. Perlakuan pupuk dilakukan pada seminggu sebelum okulasi dengan urea $2 \mathrm{~g}$ polybag $^{-1}$ dan dua minggu setelah kemunculan tunas

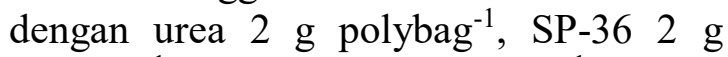
polybag $^{-1}$ dan KCL $1 \mathrm{~g}$ polybag $^{-1}$ dengan cara menaburkannya di sekeliling polybag. Bibit yang telah diokulasi kemudian 
diletakkan pada paranet dengan intensitas naungan $75 \%$. Bibit kopi yang diberikan intensitas naungan $75 \%$ nyata menghasilkan morfologi dan fisiologi yang lebih baik dibandingkan intensitas naungan 0-50\% (Rochmah, Wachjar, \& Sulistyono, 2015). Bibit diletakkan sesuai dengan rancangan percobaan dan diberikan label agar tidak tertukar. Hasil okulasi dicek setiap minggu. Pengamatan yang dilakukan dengan menggoreskan mata okulasi dengan pisau okulasi pada bagian atas mata okulasi. Okulasi berhasil dapat dilihat dari warna goresannya. Warna hijau menunjukkan okulasi berhasil dan berwarna coklat okulasi tidak berhasil (Amypalupy, 2012).

\section{HASIL DAN PEMBAHASAN Keadaan Umum}

PT Pasir Ucing Timur memiliki ketinggian tempat antara $221-350$ meter di atas permukaan laut (Mdpl). Jenis tanah yang terdapat pada PT PUT adalah Latosol.
PT PUT memiliki topografi perbukitan dengan Kemiringan tanah bentuk mendatar $\left(0-8^{\circ}\right) 41.69 \%$, landai $\left(8-15^{\circ}\right) 42.27 \%$ dan berbukit $\left(25-45^{\circ}\right) 9.12 \%$. Tekstur tanah yang dimiliki lempung berpasir dan berbatu serta $\mathrm{pH}$ tanah 6-7. Tanah di PT PUT memiliki kedalaman efektif solum 60 $\mathrm{cm}$. PT Pasir Ucing Timur memliki tipe iklim C menurut klasifikasi SchmidthFerguson. Curah hujan selama 10 tahun terakhir (2010-1019) rata - rata 2408.69 $\mathrm{mm}$ per tahun dan hari hujan dengan rata rata 157 hari per tahun dengan memiliki bulan kering selama 2.6 bulan dan bulan basah selama 7.2 bulan.

Pengamatan iklim mikro di pembibitan dilakukan untuk mengetahui kondisi iklim mikro selama pembibitan. Bibit tanaman karet memerlukan kondisi iklim yang optimal agar dapat tumbuh dan berkembang dengan baik. Pengamatan iklim mikro ditunjukkan pada Tabel 1.

Tabel 1. Iklim mikro

\begin{tabular}{ccccc}
\hline MSO & Suhu $\left({ }^{0} \mathrm{C}\right)$ & Kelembaban Udara $(\%)$ & $\mathrm{pH}$ tanah & $\begin{array}{c}\text { Intensitas } \\
\text { cahaya }\left({ }^{0} \text { Lux }\right)\end{array}$ \\
\hline 2 & 29.4 & 93 & 7.5 & 600 \\
3 & 29 & 80 & 7.5 & 350 \\
4 & 28 & 85 & 7.5 & 500 \\
5 & 28.7 & 84 & 7.5 & 600 \\
6 & 28 & 61 & 7.5 & 500 \\
7 & 28.5 & 89 & 7.5 & 300 \\
8 & 27.9 & 90 & 7.5 & 300 \\
\hline Rata-rata & 28.5 & 83.14 & 7.5 & 450 \\
\hline
\end{tabular}

Pengamatan iklim mikro menunjukkan suhu rata-rata selama penelitian berlangsung yaitu $28.5^{\circ} \mathrm{C}$, kelembaban udara $83.14 \%$, pH tanah 7.5 dan intensitas cahaya $450^{\circ}$ lux. Hasil pengamatan menunjukkan bahwa iklim mikro yang diamati sudah sesuai dengan syarat pertumbuhan bibit karet. Suhu dan intensitas cahaya yang tinggi akan mempengaruhi keberhasilan okulasi karet.
Kondisi terbentuknya kalus yang baik yaitu $21-29.51{ }^{\circ} \mathrm{C}$. Jika $>29.51{ }^{\circ} \mathrm{C}$ akan menyebabkan kerusakan kalus (Anwar \& Suwarto, 2016).

\section{Pemilihan Batang Bawah dan Mata Entres}

Batang bawah yang digunakan berasal dari benih sapuan di kebun. Batang bawah yang digunakan perlu dilakukan 
pemilihan dengan kriteria yang cukup umur, sehat, dan kuat. Perlakuan pupuk diberikan pada 1 minggu sebelum okulasi.
Pertumbuhan diameter batang bawah karet dapat dilihat pada Tabel 2 .

Tabel 2 Diameter batang bawah

\begin{tabular}{|c|c|c|c|c|c|c|c|}
\hline \multirow{2}{*}{$\begin{array}{c}\text { Perlakuan } \\
\text { Klon } \\
\text { M.Entres }\end{array}$} & \multicolumn{4}{|c|}{-Pupuk } & \multicolumn{2}{|c|}{ +Pupuk } & \multirow[b]{2}{*}{ Pert } \\
\hline & Ulangan & 1 bulan & 2 bulan & Pert & 1 bulan & 2 bulan & \\
\hline \multirow{3}{*}{ PR 261} & 1 & 1.68 & 1.85 & 0.17 & 1.78 & 1.97 & 0.19 \\
\hline & 2 & 1.70 & 1.88 & 0.18 & 1.61 & 1.80 & 0.19 \\
\hline & 3 & 1.61 & 1.80 & 0.19 & 1.64 & 1.88 & 0.24 \\
\hline Rata-rata & & 1.66 & 1.84 & 0.18 & 1.68 & 1.88 & 0.20 \\
\hline \multirow{3}{*}{ PR 300} & 1 & 1.57 & 1.73 & 0.16 & 1.62 & 1.74 & 0.12 \\
\hline & 2 & 1.69 & 1.85 & 0.16 & 1.66 & 1.84 & 0.18 \\
\hline & 3 & 1.68 & 1.76 & 0.08 & 1.71 & 1.85 & 0.14 \\
\hline Rata-rata & & 1.65 & 1.78 & 0.13 & 1.66 & 1.81 & 0.15 \\
\hline
\end{tabular}

Rata-rata diameter batang bawah yang digunakan berukuran $1.66 \mathrm{~cm}$ dan berwarna kulit batang coklat. Pertumbuhan diameter dalam jangka waktu 1 bulan PR 261 perlakuan pupuk memiliki pertumbuhan tertinggi sebesar $0.20 \mathrm{~cm}$ dan terendah perlakuan tanpa pupuk sebesar $0.18 \mathrm{~cm}$. Pada PR 300 perlakuan pupuk memiliki pertumbuhan tertinggi sebesar $0.15 \mathrm{~cm}$ dan terendah perlakuan tanpa pupuk sebesar $0.13 \mathrm{~cm}$. Pada setiap klon PR 261 dan PR 300 memiliki perbedaan pertumbuhan pada setiap perlakuannya sebesar $0.2 \mathrm{~cm}$.

Batang atas yang digunakan berasal dari kebun entres hasil okulasi yang telah berusia 15 tahun. Entres dapat digunakan setelah berusia 4 tahun setelah tanam dengan memangkasnya setiap tahun untuk menghasilkan pertunasan baru. Berdasarkan tingkat juvenilitas dan perkembangan klon terbaru kebun entres dapat dipertahankan selama 10 tahun (Siagian, 2012). Usia entres untuk okulasi coklat 7-12 bulan atau kulit batang telah berwarna coklat. Entres yang digunakan klon PR 300 dan PR 261 yang diambil dari kebun entres bercabang sekunder. Tunas yang digunakan mengarah vertikal dengan batang coklat yang akan dilakukan untuk okulasi coklat. Klon PR 300 telah berumur 15 tahun dan berdiameter $1.9 \mathrm{~cm}$ dan berwarna coklat sedangkan PR 261 telah berumur 15 tahun dan berdiamater $1.9 \mathrm{~cm}$ dan berwarna coklat. Jenis mata yang digunakan mata prima yang memilik pertumbuhan baik dan cepat.

Karakteristik PR 300 berasal dari persilangan PR 226 x PR 228 yang berasal dari Indonesia. Klon PR 300 merupakan klon penghasil lateks. Klon PR 300 merupakan jenis klon slow starter atau lambat dalam penetesan lateks dan memiliki potensi produksi pada klon yang produktif sebesar $500 \mathrm{ml}^{\text {pohon }}{ }^{-1}$ dan tidak produktif sebesar 100-200 mlpohon $^{-1}$ (Suherman, Dewi, \& Wulansari, 2020)

Karakteristik Klon PR 261 berasal dari persilangan Tjril 1 x PR 107 yang berasal dari Indonesian Rubber Research Institute. Klon PR 261 merupakan klon yang resisten terhadap penyakit Corynespora cassiicola (Nurhayati \& Aminuddin, 2010). Klon PR 261 merupakan generasi ke dua dengan potensi produksi $2.500 \mathrm{~kg} \mathrm{ha}^{-1}$ tahun $^{-1}$ atau $5 \mathrm{~kg}$ 
pohon $^{-1}$ tahun $^{-1}$. Klon PR 261 termasuk ke dalam klon anjuran penghasil lateks. Lilit batang yang dimiliki klon PR 261 pada usia 30 tahun yaitu 50-160 cm (Sahuri, 2017).

\section{Kambium}

Terbentuknya pertautan antara batang atas dan bawah dipengaruhi oleh kambium yang aktif membelah. Pengamatan kambium dilakukan untuk mengetahui kompatibilitas sambungan okulasi bibit karet. Bibit karet berhasil disambung jika warna kambium perubahan warna menjadi hijau. Hasil pengamatan kambium ditunjukkan pada Tabel 3.

Tabel 3. Prosentase perubahan warna kambium

\begin{tabular}{ccccc}
\hline Perlakuan & \multicolumn{2}{c}{ Tanpa pupuk (MSO) } & \multicolumn{2}{c}{+ pupuk (MSO) } \\
\cline { 2 - 4 } Klon & 1 & 2 & 1 & 2 \\
& & $\ldots \ldots \ldots \ldots \ldots(\%) \ldots \ldots \ldots \ldots$ & $77 \mathrm{a}$ \\
PR 261 & $22.2 \mathrm{~b}$ & $55.5 \mathrm{~b}$ & $44.4 \mathrm{a}$ & $77 \mathrm{a}$ \\
PR 300 & $44.4 \mathrm{a}$ & $55.5 \mathrm{~b}$ & $33 \mathrm{ab}$ & \\
\hline
\end{tabular}

Keterangan : angka-angka yang diikuti huruf yang sama pada kolom dan baris yang sama tidak berbeda nyata pada uji DMRT taraf $\alpha 5 \%$

Hasil pengamatan menunjukkan bahwa pada pengamatan 2 minggu setelah okulasi baik pada klon PR 261 dan PR 300 dengan penambahan pupuk menghasilkan perubahan warna kambium yang berbeda nyata jika dibandingkan tanpa pupuk. Hal ini menunjukkan penambahan pupuk berpengaruh dalam mempercepat perubahan warna kambium dibandingkan klon tanpa dipupuk. Proses penyatuan batang bawah dan batang atas terdiri atas 5 tahap. Tahap pertama adalah pengaturan cambium vascular kedua jaringan menjadi satu garis lurus, tahap kedua adalah respon penyembuhan luka, tahap ketiga pembentukan jembatan kallus, tahap keempat perbaikan luka pada xylem dan phloem pada jembatan kalus untuk pembentukan awal cambium, dan kelima pembentukan cambium vascular telah sempurna melewati jembatan kalus disertai pembentukan xylem dan phloem sekunder (Hartmann, Kester, Davies, \& Geneve, 2011).

\section{Keberhasilan okulasi}

Okulasi yang umumnya digunakan di perkebunan rakyat adalah okulasi coklat. Pengamatan keberhasilan okulasi dilakukan sampai tanaman berumur 2 minggu setelah okulasi. Hasil pengamatan keberhasilan okulasi ditunjukkan pada Tabel 4.

Tabel 4. Pengaruh Jenis Klon dan Perlakuan Pupuk terhadap Keberhasilan Okulasi

\begin{tabular}{|c|c|c|c|c|}
\hline \multirow{2}{*}{$\begin{array}{l}\text { Perlakuan } \\
\text { Klon }\end{array}$} & \multicolumn{2}{|c|}{ Tanpa pupuk (MSO) } & \multicolumn{2}{|c|}{ + Pupuk (MSO) } \\
\hline & 1 & 2 & 1 & 2 \\
\hline & & $\%$ & & \\
\hline PR261 & $100 \mathrm{a}$ & $100 \mathrm{a}$ & $100 \mathrm{a}$ & $100 \mathrm{a}$ \\
\hline PR300 & $89 \mathrm{ab}$ & $56 b$ & $100 \mathrm{a}$ & $89 \mathrm{ab}$ \\
\hline
\end{tabular}

Ket : angka-angka yang diikuti huruf yang sama pada kolom dan baris yang sama tidak berbeda nyata pada uji DMRT taraf $\alpha 5 \%$

Pada Tabel 4 dapat diketahui bahwa pada perlakuan klon PR 261 baik tanpa dipupuk dan dipupuk menunjukkan tingkat keberhasilan $\quad 100 \%$ jika dibandingkan perlakuan klon PR 300 tanpa dipupuk. Penambahan pupuk pada klon PR 
300 menunjukkan keberhasilan okulasi lebih tinggi dibandingkan tanpa dipupuk. Tingkat keberhasilan okulasi karet dipengaruhi oleh faktor internal dan eksternal. Keberhasilan okulasi yang tinggi pada klon PR 261 diduga karena faktor internal genetik. Perbedaan tingkat keberhasilan okulasi disebabkan oleh kompatibilitas atau kecocokan antara batang atas dan batang bawah saat dilakukan okulasi (Boerhendhy \& Amypalupy, 2010). Peningkatan keberhasilan okulasi pada bibit karet dapat dilakukan dengan menambahkan input berupa unsur hara. Penambahan unsur hara pada bibit karet akan mempercepat pelekatan antara batang bawah dan entres.

\section{Pertumbuhan daun}

Daun merupakan tempat tanaman melakukan fotosintesis. Pertumbuhan daun pada bibit tanaman akan dapat menunjang pertumbuhan bibit tanaman karet. Hasil pengamatan pertumbuhan daun ditunjukkan pada Tabel 5.

Tabel 5. Prosentase Pertumbuhan Daun

\begin{tabular}{ccccccccc}
\hline Perlakuan & \multicolumn{4}{c}{ Tanpa pupuk (MSO) } \\
\cline { 2 - 9 } Klon & 1 & 2 & 3 & 4 & 1 & 2 & 3 & 4 \\
\hline & & \multicolumn{4}{c}{$\ldots \ldots \ldots \ldots \ldots \ldots \% \ldots \ldots \ldots \ldots \ldots \ldots$} \\
PR261 & 44.45 & 22.22 & 22.22 & $55.56 \mathrm{~b}$ & 33.33 & 22.22 & 11.11 & $77.78 \mathrm{a}$ \\
PR300 & 55.56 & 11.11 & 11.11 & $\mathbf{6 6 . 6 7 a b}$ & 55.56 & 33.33 & 22.22 & $\mathbf{7 7 . 7 8 a}$ \\
\hline
\end{tabular}

Keterangan : angka-angka yang diikuti huruf yang sama pada kolom dan baris yang sama tidak berbeda nyata pada uji DMRT taraf $\alpha 5 \%$

Hasil pengamatan pertumbuhan daun menunjukkan bahwa pada 4 minggu setelah okulasi, perlakuan pupuk nyata menghasilkan pertumbuhan daun lebih tinggi dibandingkan tanpa dipupuk baik pada klon PR 261 dan PR 300. Hasil penelitian tersebut menunjukkan bahwa pertumbuhan daun dipengaruhi oleh unsur hara. Hara nitrogen yang diserap tanaman berperan dalam merangsang pertumbuhan vegetative yaitu daun, batang dan pembentukan klorofil. Hara kalium berperan dalam mengatur membuka dan menutupnya stomata sehingga $\mathrm{O}_{2}$ dan $\mathrm{CO}_{2}$ dapat dimanfaatkan oleh tanaman untuk respirasi dan fotosintesis (Khalik, Bahrun, \& Safuan, 2017).

\section{Munculnya tunas}

Pada Tabel 6 disajikan data prosentase munculnya tunas pada bibit karet. Kemunculan tunas ini menunjukkan tingkat keberhasilan okulasi pada bibit. Hasil pengamatan menunjukkan bahwa perlakuan klon PR 261 nyata menghasilkan kemunculan tunas lebih baik dibandingkan perlakuan klon PR 300.

Tabel 6. Pengaruh Perlakuan Jenis Klon dan Pupuk terhadap Prosentase Bibit Bertunas

\begin{tabular}{ccccccc}
\hline Perlakuan & \multicolumn{3}{c}{ Tanpa pupuk (HSO) } \\
\cline { 2 - 7 } Klon & 7 & 12 & 15 & 7 & 12 & 15 \\
\hline & \multicolumn{5}{c}{$\ldots \ldots \ldots \ldots \ldots . \ldots \ldots \ldots \ldots \ldots$} \\
PR261 & $22.22 \mathrm{ab}$ & $77.78 \mathrm{a}$ & $100 \mathrm{a}$ & $44.45 \mathrm{a}$ & $66.67 \mathrm{ab}$ & $88.9 \mathrm{ab}$ \\
PR300 & $\mathbf{0 . 0 0 b}$ & $\mathbf{2 2 . 2 2 b}$ & $\mathbf{3 3 . 3 3 b}$ & $11.11 \mathrm{ab}$ & $77.79 \mathrm{a}$ & $88.9 \mathrm{ab}$ \\
\hline
\end{tabular}

Keterangan : angka-angka yang diikuti huruf yang sama pada kolom dan baris yang sama tidak berbeda nyata pada uji DMRT taraf $\alpha 5 \%$ 
Hasil pengamatan menunjukkan bahwa jenis klon berpengaruh terhadap perkecambahan tunas. Klon PR 261 pada umur 15 hari setelah menunjukkan perkecambahan tunas sudah $100 \%$. Perkecambahan tunas ini menunjukan klon PR 261 memiliki kompatibilitas dengan batang bawah. Munculnya tunas pada bibit karet diduga disebabkan juga oleh faktor hormone. Hormon yang berpengaruh yaitu auksin dan sitokinin. Hormon auksin dan sitokinin ini berperan dalam memobilisasi hara dan asimilat untuk pertumbuhan. Hormon sitokinin mempunyai peranan yang penting pada pembengtukan cabang lateral dan merangsang pembelahan sel yang akan menjadi tunas, cabang dan daun (Pratomo, Hanum, \& Putri, 2016).

\section{Tinggi bibit}

Pengamatan tinggi bibit hanya dapat dilaksanakan sampai 2 Bulan setelah okulasi. Hasil pengamatan tinggi bibit menunjukkan bahwa perlakuan klon PR 261 yang ditambahkan pupuk menghasilkan tinggi bibit yang nyata lebih tinggi dibandingkan klon PR 300 tanpa dipupuk.

Tabel 7. Pengaruh Perlakuan Jenis Klon dan Pupuk terhadap Tinggi Bibit

\begin{tabular}{ccccc}
\hline Perlakuan & \multicolumn{2}{c}{ Tanpa pupuk (BSO) } & \multicolumn{2}{c}{+ Pupuk (BSO) } \\
\cline { 2 - 5 } Klon & 1 & 2 & 1 & 2 \\
\hline & & $\ldots \ldots \ldots \mathrm{cm} \ldots \ldots$. & \\
PR261 & $0.19 \mathrm{ab}$ & $2.51 \mathrm{ab}$ & $0.44 \mathrm{a}$ & $7.41 \mathrm{a}$ \\
PR300 & $\mathbf{0 . 0 2 b}$ & $\mathbf{0 . 2 9 b}$ & $0.09 \mathrm{ab}$ & $2.83 \mathrm{ab}$ \\
\hline
\end{tabular}

Keterangan : angka-angka yang diikuti huruf yang sama pada kolom dan baris yang sama tidak berbeda nyata pada uji DMRT taraf $\alpha 5 \%$

Pertumbuhan tinggi bibit dipengaruhi oleh faktor genetik dan lingkungan. Pemberian hara pada bibit tanaman karet akan membantu pertumbuhan bibit menjadi lebih baik. Tanaman untuk dapat tumbuh dan berkembang memerlukan unsur hara yang cukup. Unsur hara $\mathrm{N}$ yang terdapat di dalam urea berperan dalam proses fotosintesis. Unsur hara nitrogen berperan dalam pembengtukan klorofil. Klorofil yang tersedia banyak akan meningkatkan penangkapan cahaya sehingga laju fotosintesis akan meningkat. Fotosintat yang dihasilkan akan digunakan oleh tanaman untuk pertumbuhan dan perkembangannya. Unsur hara $\mathrm{P}$ pada tanaman berperan dalam merangsang pertumbuhan akar. Pertumbuhan akar yang baik akan meningkatkan laju penyerapan hara yang dibutuhkan oleh tanaman. Unsur hara $\mathrm{K}$ berperan dalam membantu proses fotosintesis, pembentukan protein dan karbohidrat, meningkatkan resistensi terhadap serangan hama, sebagai katalisator dalam proses transformasi tepung, gula dan lemak tanaman (Tisdale, Nelson, \& Beaton, 2003).

\section{Diameter batang}

Pengamatan diameter batang dilakukan untuk melihat pertumbuhan dan perkembangan bibit karet. Hasil pengamatan diameter batang ditunjukkan pada Tabel 8. 
Tabel 8. Pengaruh Perlakuan Jenis Klon dan Pupuk terhadap Diameter Batang

\begin{tabular}{ccccc}
\hline Perlakuan & \multicolumn{2}{c}{ Tanpa pupuk (BSO) } & \multicolumn{2}{c}{+ Pupuk (BSO) } \\
\cline { 2 - 5 } Klon & 1 & 2 & 1 & 2 \\
\hline & & $\ldots \ldots \ldots \ldots \ldots \ldots \ldots \ldots \ldots \ldots \ldots \ldots$ & \\
PR261 & 0 & $0.11 \mathrm{ab}$ & 0 & $0.29 \mathrm{a}$ \\
PR300 & 0 & $\mathbf{0 . 0 0 b}$ & 0 & $0.21 \mathrm{ab}$ \\
\hline
\end{tabular}

Keterangan : angka-angka yang diikuti huruf yang sama pada kolom dan baris yang sama tidak berbeda nyata pada uji DMRT taraf $\alpha 5 \%$

Hasil pengamatan menunjukkan bahwa perlakuan klon PR 261 yang ditambahkan pupuk nyata menghasilkan diameter lebih besar jika dibandingkan perlakuan PR 300 tanpa dipupuk. Pada klon PR 300 yang ditambahkan pupuk menghasilkan diameter batang yang tidak nyata dengan klon PR 261 yang ditambahkan pupuk. Pertambahan diameter batang bibit karet diduga dipengaruhi oleh supplai hara. Pertumbuhan diameter bibit karet dipengaruhi oleh supplai hara dan nutrisi yang diambil oleh batang bawah atau scion (Sari \& Supijatno, 2015).

\section{KESIMPULAN}

Berdasarkan hasil penelitian menunjukkan bahwa perlakuan jenis klon dan penambahan pupuk berpengaruh terhadap keberhasilan okulasi serta pertumbuhan bibit karet. Jenis klon PR 261 memiliki keberhasilan okulasi lebih tinggi dan pertumbuhan bibit lebih baik dibandingkan klon PR 300. Penambahan pupuk pada proses okulasi berpengaruh terhadap keberhasilan okulasi dan pertumbuhan bibit karet dibandingkan perlakuan tanpa pupuk. Kombinasi perlakuan klon PR 261 dan pupuk urea $4 \mathrm{~g}$ polybag $^{-1}$. Sp-36 2 g polybag $^{-1}$ dan KCL 1 $\mathrm{g}$ polybag $^{-1}$ meningkatkan pertumbuhan bibit karet.

\section{DAFTAR PUSTAKA}

Amypalupy, K. (2012). Produksi Bahan Tanam Karet. Sumatera Selatan: Balai Penelitian Karet Sembawa.
Anwar, R., \& Suwarto. (2016). Pengelolaan Tanaman Karet (Hevea brasiliensis Muell. Arg) di Sumatera Utara dengan Aspek Khusus Pembibitan. Bul. Agrohorti, 94-103. Retrieved From https://doi.org/10.29244/agrob.4.1

Boerhendry, I., \& Amypalupi, K. (2010). Optimalisasi Produktivitas Karet melalui Penggunaan Bahan Tanam, Pemeliharaan, Sistem eksploitasi dan Peremajaan Tanaman. Jurnal Litbang Pertanian, 23-30. Retrieved From http://dx.doi.org/10.21082/jp3.v30n 1.2011.p23-30

Boerhendy, I. (2013). Prospek Perbanyakan Bibit Karet Unggul dengan Teknik Okulasi Dini. Jurnal Penelitian dan Pengembangan Pertanian, 85-90. Retrieved From https://dx.doi.org/10.21082/jp3.v32n 2.2013.p85-90

Ditjenbun. (2018). Karet : Statistika Perkebunan Indonesia 2017-2019. Jakarta: Direktorat jenderal perkebunan.

Gomez, K., \& Gomez, A. (2007). Prosedur Statistik untuk Penelitian Pertanian. Jakarta: Universitas Indonesia.

Hadi, H. (2010). Meningkatkan Produktivitas berbasis Mutu fisiologis bahan tanaman. Majalah Hevea, 42-44. 
Hartmann, H., Kester, D., Davies, F., \& Geneve, R. (2011). Plant Propagation: Principles and Practices. New York: Prentice Hall/Pearson.

Hulu, P., \& Supijatno. (2016). Respon Pertumbuhan Bibit Karet (Hevea brasiliensis Muell. Arg) terhadap Pemberian Inokulan Cendawan Mikoriza Arbuskula dan Pemupukan Fosfor. Bul. Agrohorti, 359-367. Retrieved From https://doi.org/10.29244/agrob.4.3

Khalik, M., Bahrun, A., \& Safuan, L. (2017). Hubungan Kadar Hara N, P, $\mathrm{K}$ Tanah dan Jaringan Tanaman terhadap Pertumbuhan dan Produksi Tanaman Sagu (Metroxylon sagu Rottb). Berkala Penelitian Agronomi, 19-30. Retrieved Form http://dx.doi.org/10.33772/bpa.v5i2. 7562

Nurhayati, F., \& Aminuddin, M. (2010). Ketahanan Enam Klon Karet terahadap Infeksi Corynespora cassiicola Penyebab Penyakit Gugur Daun. Journal HPT Tropika, 47-51. Retrieved From https://dx.doi.org/10.23960/j.hptt.11 047-51

Pratomo, B., Hanum, C., \& Putri, L. A. (2016). Pertumbuhan Okulasi Tanaman Karet (Hevea brasiliensis Muell Arg) dengan Tinggi Penyerongan Batang Bawah dan Benzilaminopurin (BAP) pada Pembibitan Polibeg. Jurnal Pertanian Tropik, 119-123. Retieved From https://doi.org/10.32734/jpt.v3i2.29 65
Rochmah, H., Wachjar, A., \& Sulistyono, E. (2015). The Growth of Arabica Coffee Seedling (Coffea arabica Linn) on Various Watering Time Intervals and Shade Intensities. Asian Journal of Applied Sciences, 485-491. Retrieved From https://www.ajouronline.com/index. php/AJAS/article/view/3190

Sahuri. (2017). Model Pendugaan Volume Pohon Karet saat Peremajaan di Sembawa Sumatera Selatan. Jurnal Penelitian Hutan Tanaman, 139153. Retrieved From https://dx.doi.org/10.20886/jpht.201 7.14.2.141-155

Sari, P., \& Supijatno. (2015). Pengelolaan Pembibitan Karet (Hevea brasiliensis Muell. Arg) di Balai Penelitian Sembawa, Palembang, Sumatera Selatan. Bul. Agrohorti, 252-262. Retrieved From https://doi.org/10.29244/agrob.3.2

Selwina, A., \& Sutejo, H. (2017). Pengaruh Pupuk Kandang Kambing dan Pupuk NPK Phonska terhadap Pertumbuhan Bibit Karet Okulasi (Hevea brasiliensis Muell.Arg) Klon PB 260. Agrivor, 17-26. Retrieved From https://dx.doi.org/10.31293/af.v16il. 2582

Siagian, N. (2012). Juvenilitas Sumber Mata Okulasi dan Pengelolaan Kebun Entres. Warta Perkaretan, 57-65. Retrieved From https://doi.org/10.22302/ppk.wp.v31 i2.267

Suherman, C., Dewi, I., \& Wulansari, R. (2020). Pengaruh Metode Aplikasi dan Dosis Stimulan Cair terhadap Produksi Lateks pada Tanaman Karet Klon PR 300 Umur 25 tahun. Journal Kultivasi, 1023-1029. 
Retrieved

From

https://doi.org/10.24198/kultivasi\%2

0

Tisdale, S., Nelson, \& Beaton, J. D. (2003).

Soil Fertility and Fertilizer. New York: Mac Millian Pub.

Tjahyana, B., \& Ferry, Y. (2011).

Revegetasi Lahan Bekas Tambang Timah dengan Tanaman Karet (Hevea brasiliensis). Seminar Nasional Inovasi Teknologi Perkebunan (hal. 117-123). Jakarta: Pusat Penelitian dan Pengembangan Perkebunan. 